\title{
Analysis of Zakat Accounting and the Role of the Internal Control System based on Financial Accounting Standards Guidelines (PSAK 109) Zakat Agency in Indonesia
}

\author{
Hari Setiyawati ${ }^{1}$ \\ ${ }^{1}$ Department of Accounting, Universitas Mercu Buana, Jakarta, Indonesia \\ Correspondence: Hari Setiyawati, Department of Accounting, Universitas Mercu Buana, Jakarta, Indonesia.
}

Received: July 3, 2020

Accepted: August 26, 2020

Online Published: December 24, 2020

doi:10.5430/ijfr.v12n1p192

URL: https://doi.org/10.5430/ijfr.v12n1p192

\begin{abstract}
This research was carried out because of the phenomenon of the large potential of zakat in Indonesia and the large number of zakat funds that were corrupted due to unaccountable financial reporting. Many payers of zakat (muzakki) still do not believe in National Zakat Agency (BAZNAS), so zakat payments are often not made through the official of BAZNAS. This research was carried out through a survey which was designed to examine the accountability of financial reporting at the amil zakat and amil zakat institutions in Jakarta and Banten, related to internal control competencies and financial reporting accountability. The expected results of this study are an increase in the accountability of financial reporting by conducting sharia accounting training for staff in amil zakat and amil zakat institutions in Jakarta and Banten. The goal of this study is to contribute scientifically to the science of sharia accounting, specifically accounting for zakat, and to assist accounting departments in preparing financial statements. The results of this study state that compliance with the application of zakat accounting with Financial Accounting Standards Guidelines (PSAK 109) had no significant effect on financial reporting accountability, while the role of the internal control system had a significant positive effect on financial reporting accountability.
\end{abstract}

Keywords: financial reporting accountability, Zakat Accounting PSAK 109, internal control system

\section{Introduction}

Accountability is a well-known term in the State Administration of the Republic of Indonesia. It was a driver of the establishment of Law Number 28 years of 1999 concerning the implementation of a country clean and free from corruption, collusion and nepotism. In the Big Indonesian Dictionary, accountability is defined as about things that are responsible or circumstances that can be held accountable. While Trisnawati \& Megawati (2015) defined as Accounting is the art of recording, classifying, summarizing, interpreting, and communicating in certain ways and in monetary measures, transactions and economic events of a legal or social entity. The goal is to improve the integrity, proper management and transparency, in the financial report (Doktoralina \& Bahari, 2019; Setiyawati \& Doktoralina, 2019).

Zakat, in general, can essentially be defined as an act of obedience by a Muslim who seeks to purify their wealth, cleanse their souls and benefit themselves and others (Doktoralina et al., 2019; Taha et al., 2017). Zakat plays an important role in increasing social inequality and eradicating poverty (Doktoralina et al., 2020; Doktoralina, Bahari, Herliansyah, et al., 2018). With the proper and accurate data collection on the poor and poor people, it is hoped that the distribution of zakat will be right on target. Zakat receipts have not reached their potential in Indonesia, and one factor is the decision of muzakki not to distribute zakat, issuing a portion of assets or income / income for an interest ruled by Islamic teachings (infaq), and practicing property in the way of Allah sincerely without expecting anything in return, and solely expecting His approval as proof of the truth of one's faith.(shodaqoh) to existing zakat management organizations. The muzakki did not trust these organizations, prompting them to directly channel their zakat funds to those who were entitled. The muzakki's distrust factor in the management of funds by zakat management organizations, both the BAZNAS and the amil zakat institution (LAZ) in Indonesia, was due to lack of transparency in the financial reports and accountability of BAZ, LAZ and amil as assigned to implement the Collection to the level of distribution of zakat. Also, muzakki did not get greater benefits if the zakat funds were channelled through BAZ and LAZ compared to direct distribution (Doktoralina, Bahari, \& Abdullah, 2018; 
Septiarini, 2011).

Another phenomenon that exists today is the lack of trust in the LAZ towards the management of zakat itself. Indonesian people in general have not distributed zakat to institutions that already have permission to manage zakat. The challenge for zakat management institutions is to foster trust in the community. Although LAZ is essentially an institution based on religious concepts, assigning to them a form of high accountability to Allah SWT, people still need information as a reference for evaluating the performance of LAZ. Transparency issues at LAZ should not be ignored (Dulkiah, 2017).

In carrying out its operational activities, the non-profit organization LAZ receives donations in the form of objects and money. To maintain the trust of the people who have donated part of their wealth, LAZ managers are expected to be able to present financial statements of zakat in accordance with Financial Accounting Standards Guidelines (PSAK 109). By preparing an accurate financial report, zakat accounting can be applied effectively (Nikmatuniayah \& Marliyati, 2015).

From several existing studies, it can be concluded that at present there are still Amil Zakat institutions that have not implemented the accounting zakat according to PSAK 109. Their internal controls remain weak, resulting in deviations from zakat funds which reduce accountability of financial statements. Based on this background, the issue addressed in this study is whether the application of zakat accounting based on PSAK 109 and the role of the internal control system affects the accountability of financial reporting. This study aims to examine and analyse these effects.

\section{Literature Review}

\subsection{Theoretical Study}

Base on accountability theory by Vance et al. (2015) and the importance of internal control as stated by Committe of Sponsoring Organization of the Treadway Commission (2013), this study emphasizes the importance of internal control to the reliability of financial reports, effectiveness and efficiency of operations and compliance toward applicable laws and regulations. The goal is to prevent errors in explaining actions in managing the potential for positive or negative consequences.

\subsection{Financial Reporting Accountability}

Accountability is intended as the principle of regulating the roles and responsibilities of management so that company administration can be accountable and support efforts to guarantee the balance of management and shareholders' interests, as overseen by the board of directors (Effendi, 2016: p. 13).

The principle of Amanah (accountability) is also explained in the Qur'an, Surat al-Baqarah verse 283: "... the person who is believed to be obliged to fulfil his mandate, and devote to the God. Do not hide your testimony. And Allah knows all that you do."

According to Mahmudi (2013: p. 9), public accountability is defined as: "Obligation of agents (government) to manage resources, report, and disclose, all activities and activities related to the use of public resources to the credentials."

Public accountability, according to Bastian (2010 p. 385), is: "The obligation to convey accountability or to answer, explain performance, and the actions of a person or legal entity and collective leadership or organization to those who have rights or authority to ask for information or accountability." Mardiasmo (2018) states that public accountability is the obligation of the trustee (agent) to provide accountability, present, report, and disclose all activities and activities which are his responsibility to the trustee (principal) who has the right and authority to request responsibility (Setiyawati, 2013; Setiyawati \& Doktoralina, 2019). Public accountability according to Mursyidi (2013: p. 44) is: "To account for the management of resources and the implementation of policies entrusted to reporting entities in achieving periodically set goals."

\subsection{Zakat Accounting Based on PSAK 109}

The accounting discussed here refers to PSAK 109, the scope of which is limited to amil zakat which receives and distributes zakat, infaq, and shodaqoh. Sharia accounting deals with the recognition and recording of transactions and the disclosure of rights and obligations fairly (Widiana, 2018). Allah SWT said: "O ye who believe! When ye deal with each other, in transactions involving future obligations in a fixed period of time, reduce them to writing Let a scribe write down faithfully as between the parties: let not the scribe refuse to write: as Allah Has taught him, so let him write". (Surat al-Baqarah: 282)

This PSAK 109 is a reference of several Indonesian Ulema Council (MUI) a binding ruling in religious matters 
(fatwa's), namely MUI Fatwa Number 8 year of 2011 concerning Amil Zakat, Fatwa MUI Number 13 year of 2011 concerning Law zakat on illicit property, MUI Fatwa No. 14 of 2011 concerning Distribution of Assets Zakat in the form of assets under management and MUI Fatwa Number 15 year of 2011 concerning Withdrawal, Maintenance and Distribution Zakat.

\subsection{The Role of the Internal Control System}

Internal control is a process that is designed, implemented, and maintained by management and other employees to provide adequate confidence in achieving the entity's goals regarding the reliability of effective financial statements, efficiency of operations and compliance with laws and regulatory provisions (Tuanakotta, 2015: p. 93). According to Susanto (2017: p. 95), "Internal Control can be defined as a process that is influenced by the board of directors, management and employees designed to provide assurance that organizational goals will be achieved through: efficiency and effectiveness of operations, presentation of financial statements that can trusted and obedience to the law.

\subsection{Framework}

There are amil zakat institutions that have applied zakat accounting to their financial statements, but there are still many that have implemented only partially or not at all. According to Doktoralina \& Bahari (2018); Hermawan \& Astriana (2010), the financial report data of a amil zakat institution can be presented in a complete manner, revealed by the presentation of financial statements that are simple and accountable. Ritonga (2017) concluded that in presenting the financial statements of BAZNAS North Sumatra, it had applied accounting for zakat but was not fully in accordance with the standard. Lubis \& Saragih (2018) concluded the same: that the North Sumatra amil zakat agency had not fully implemented PSAK 109 in accounting and financial reporting. Trisnawati \& Megawati (2015) came to the different conclusion that the application of PSAK 109 concerning accounting for zakat at the BAZNAS in Pekanbaru is a proof of the commitment of the management in realizing transparency and accountability for the management of zakat, infaq, and shodaqoh. The results of Nikmatuniayah (2014) research on the internal control system at BAZNAS, found that there were weaknesses in complying with internal control. Aisyah (2013) also states that there are weaknesses in the application of the zakat fund internal control system at the amil zakat agency in Pare-pare.

Based on a review of theories and previous research, in this study a framework of thought was constructed as shown in Figure 1.

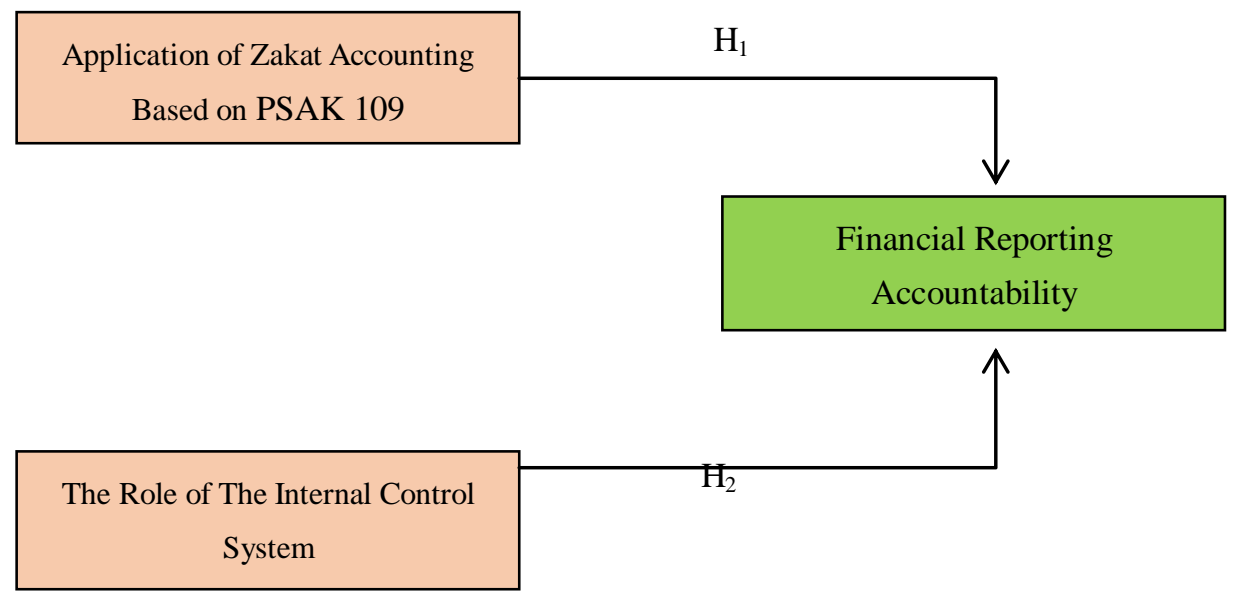

Figure 1. Theoretical framework

Based on the study of literature on the theory of accountability and the framework that has been built, this research proposes the following hypotheses:

$\mathrm{H}_{1}$ : The application of zakat accounting based on PSAK 109 has an effect on financial reporting accountability.

$\mathrm{H}_{2}$ :The internal control system has an effect on financial reporting accountability. 


\section{Methods}

\subsection{Research Design}

This research is an exploratory study with a type of causal study where the researcher wants to find the cause of one or more problems (Sekaran \& Bougie, 2016). This study examines the effect of zakat accounting practises based on PSAK 109 and the role of the internal control system in financial reporting accountability. This study intends to explain the causal relationship between variables through testing hypotheses. Some of the things that will be discussed include: research objects; research methods; population and samples; types and sources; data collection techniques; testing data; and methods of data analysis.

\subsection{Selection Methods and Data Collection}

The target population as a whole unit of analysis in this study is all amil zakat agencies and the amil zakat institutions of the provincial, regency, city, and regional governments in the Jakarta and Banten regions, totalling 42 entities. All members of the population are sampled; therefore, the sampling method is called a saturated sample. The observation unit in this study is the accounting and finance section. The names of amil zakat agencies and amil zakat institutions in Jakarta and Banten that are members of the sample can be seen in Table 1 below.

Table 1. List of sample members

\begin{tabular}{clcl}
\hline No & Institutions & No & Institutions \\
\hline 1 & Badan Amil Zakat DKI & 22 & Yatim Mandiri Jakarta Selatan \\
2 & Badan Amil Zakat Jakarta Selatan & 23 & Yayasan Baitul Maal BRI Jakarta \\
3 & Badan Amil Zakat Jakarta Pusat & 24 & Yayasan Baitul Maal BRI Jakarta \\
4 & Badan Amil Zakat Jakarta Utara & 25 & Baznas Banten \\
5 & Badan Amil Zakat Jakarta Barat & 26 & Baznas Serang \\
6 & Rumah Zakat Indonesia DKI Jakarta & 27 & Baznas Cilegon \\
7 & Rumah Zakat Indonesia Banten & 28 & Baznas Pandeglang \\
8 & Dompet Dhuafa Jakarta Selatan & 29 & LAZ Harfa \\
9 & Dompet Dhuafa Serpong & 30 & Dompet Dhuafa Tangerang \\
10 & LAZ Alazhar & 31 & Dompet Dhuafa Jakarta Barat \\
11 & Lazismu & 32 & Yatim Mandiri Jakarta Timur \\
12 & DPU Dompet Dhuafa Jakarta & 33 & Yatim Mandiri Jakarta Barat \\
13 & DPU Dompet Dhuafa Banten & 34 & Yatim Mandiri Banten \\
14 & Baitul Maal Hidayatullah Jakarta & 35 & Inisiatif Zakat Indonesia Banten \\
15 & Baitul Maal Hidayatullah Banten & 36 & Inisiatif Zakat Indonesia Banten \\
16 & Baitul Maal Muamalat & 37 & Lazis PLN \\
17 & LAZNAS BSM Umat & 38 & LAZ LMI Nasional DKI Jakarta \\
18 & Portal Infaq & 39 & Bamuis BNI \\
19 & Lazis Yayasan Amaliyah Astra & 40 & MTT Telkomsel \\
20 & Lazis Dewan Dakwah Banten & 41 & Mandiri Amal Insani \\
21 & Lazis Dewan Dakwah DKI Jakarta & 42 & Amil Zakat Nurul Hayat Jakarta \\
\hline
\end{tabular}

Source: www.forumzakat.org.id dan www.Baznas.org.id

\subsection{Data Analysis Method}

Data were analysed using multiple regression models and processed using SPSS. The analysis used in this research is descriptive statistics analysis, data quality test, classical assumption test, model suitability test, and hypothesis test. 


\section{Descriptive Statistics Analysis}

The following is a table of compliance variables for the accounting application of zakat PSAK 109.

Table 2. Description of application of Zakat Accounting based on PSAK 109 variables

\begin{tabular}{clcc}
\hline No & \multicolumn{1}{c}{ Dimension } & Average Score & Category \\
\hline 1 & Compliance of Recognition and Measurement of Zakat & 4.07 & High \\
& Practise & & \\
2 & Compliance of Financial Statement Presentation & 4.37 & Very High \\
3 & Compliance of Zakat Transactions Disclosure by amil & 4.21 & High \\
& Average total score & 12.65 & \\
\hline & Average score & 4.21 & High
\end{tabular}

Source: Data processed (2019)

Table 2 shows that compliance of zakat accounting practice based on PSAK 109 is in the High category; thus, it can be concluded that compliance of accounting zakat practice based on PSAK 109 in the Jakarta and Banten provinces is already good.

The role of the internal control system variables have five dimensions: environmental control, integrity, values, and ethics; risk assessment; control activities; information and communication; and monitoring. Based on the range of values and categorization, each variable and indicator variable for the role of the internal control system can be seen in Table 3 below.

Table 3. Description of the role of internal control system variables

\begin{tabular}{clcc}
\hline No & \multicolumn{1}{c}{ Dimension } & Average Score & Category \\
\hline 1 & Environmental Control, Integrity, Values, and Ethics & 4.55 & Very High \\
2 & Risk Assessment & 4.35 & Very High \\
3 & Control Activities & 4.34 & Very High \\
4 & Information and Communication & 4.34 & Very High \\
5 & Monitoring & 4.26 & Very High \\
\hline & Average score & 4.37 & Very High \\
\hline
\end{tabular}

Source: Data processed (2019)

Table 3 illustrates that the role of the internal control system has an average score of 4.37 and is included in the very high category. The lowest score is 4.26 for monitoring, while the highest score is 4.55 for control environment, integrity, values, and ethics. It can be concluded that the role of the LAZ internal control system in Jakarta and Banten provinces has been very good.

The following is a table of Financial Reporting Accountability Variables.

Table 4. Description of financial reporting accountability variables

\begin{tabular}{llcl}
\hline No & \multicolumn{1}{c}{ Dimension } & $\begin{array}{c}\text { Average } \\
\text { Score }\end{array}$ & Category \\
\hline 1 & Mechanism Reporting and Mechanism distribution of funds & 4.48 & Very High \\
\hline & Average score & 4.48 & Very High
\end{tabular}

Source: Data processed (2019) 
Table 4 shows that the financial reporting accountability variable has an average score of 4.48 and is included in the very high category. Based on these results, it can be interpreted that the financial reporting accountability of LAZ in Jakarta and Banten provinces has been very good.

\section{Validity and Reliability Test Results}

Based on the results of the validity test, it can be seen that all variables consisting of compliance with the accounting application of zakat PSAK 109 and the role of the internal control system on financial reporting accountability are valid or can be maintained, as shown in the following table.

Table 5. Validity Test Results

\begin{tabular}{|c|c|c|c|}
\hline Variable \& Dimension & Indicator & Loading & Result \\
\hline & & Factor & \\
\hline \multirow[t]{5}{*}{$\begin{array}{l}\mathrm{X}_{1-} \text { Compliance of Recognition and } \\
\text { Measurement of Zakat Practise }\end{array}$} & $\begin{array}{l}\text { Receipt of zakat is recognized when cash or } \\
\text { non-cash assets are received. }\end{array}$ & 0.606 & Valid \\
\hline & $\begin{array}{l}\text { Zakat received from muzakki is recognized as an } \\
\text { increase in zakat funds in the amount of: the } \\
\text { amount received, if in the form of cash; fair value, } \\
\text { if in non-cash form. }\end{array}$ & 0.556 & Valid \\
\hline & $\begin{array}{l}\text { If muzakki determines the mustahik (the people } \\
\text { that receives the distribution of zakat) through } \\
\text { amil, then there is no part of amil for the zakat } \\
\text { received, but amil can obtain the fee of charge for } \\
\text { a service (ujrah) from muzakki, excluding zakat } \\
\text { funds. Ujrah is recognized as an addition to the } \\
\text { amil fund. }\end{array}$ & 0.566 & Valid \\
\hline & $\begin{array}{l}\text { Decreasing the asset value of zakat is recognized: } \\
\text { as a deduction from zakat funds if it is not caused } \\
\text { by amil's negligence; loss and reduction of amil } \\
\text { funds, if caused by amil negligence. }\end{array}$ & 0.700 & Valid \\
\hline & $\begin{array}{l}\text { Zakat distributed to mustahik, including amil, is } \\
\text { recognized as a deduction from zakat funds in the } \\
\text { amount given or the carrying amount. }\end{array}$ & 0.699 & Valid \\
\hline $\begin{array}{l}\text { Compliance of Financial Statement } \\
\text { Presentation }\end{array}$ & $\begin{array}{l}\text { Amil presents zakat funds, infaq/charity funds, } \\
\text { and amil funds separately in the statement of } \\
\text { financial position. }\end{array}$ & 0.411 & Valid \\
\hline \multirow[t]{4}{*}{$\begin{array}{l}\text { Compliance of Zakat Transactions } \\
\text { Disclosure by Amil }\end{array}$} & $\begin{array}{l}\text { Amil funds are presented separately in the } \\
\text { statement of financial position. }\end{array}$ & 0.582 & Valid \\
\hline & $\begin{array}{l}\text { The zakat distribution policy, such as determining } \\
\text { the priority scale of zakat distribution and } \\
\text { non-amil mustahik. }\end{array}$ & 0.565 & Valid \\
\hline & $\begin{array}{l}\text { The policy of distributing zakat for amil and } \\
\text { non-amil mustahik, such as percentage sharing, } \\
\text { reasons, and policy consistency. }\end{array}$ & 0.464 & Valid \\
\hline & $\begin{array}{l}\text { Details of the amount of distribution and zakat for } \\
\text { each mustahik. }\end{array}$ & 0.558 & Valid \\
\hline \multirow{3}{*}{$\begin{array}{l}\mathrm{X}_{2} \text { - Environmental Control, } \\
\text { Integrity Value, and Ethics }\end{array}$} & Maintain ethics in the organization & 0.501 & Valid \\
\hline & $\begin{array}{l}\text { Being able to identify the tasks and functions of } \\
\text { each position in the agency. }\end{array}$ & 0.594 & Valid \\
\hline & $\begin{array}{l}\text { Establish and divide the activities needed to } \\
\text { complete the tasks and functions of each position }\end{array}$ & 0.450 & Valid \\
\hline
\end{tabular}


Risk assessment

Control Activities

Information and Communication

Monitoring in the agency.

Division of authority is carried out in accordance with functions and tasks.

Identifying risks that hinder agency goals effectively and efficiently.

Identifying the risks that hinder internal and external parties.

Design and use documentation correctly.

The head of the agency needs to ensure that all events and aspects of the transaction are not controlled by only one person.

The leadership of an institution needs to monitor that all events and aspects of the transaction are not controlled by only one person.

Communicate identification plans, policies and procedures in physical security of all employees.

The leadership of the agency implements the determination and implementation of the identification plan, policies and procedures in physical security of all employees.

Having reliable and relevant information for both financial and non-financial information.

Able to provide various forms and means of communication, managing, developing and continuously updating information systems.

Carry out ongoing monitoring.

$0.720 \quad$ Valid

Conduct a separate evaluation and follow up on review recommendations.

$0.451 \quad$ Valid

$0.521 \quad$ Valid

$0.642 \quad$ Valid

$0.625 \quad$ Valid

$0.581 \quad$ Valid

$0.565 \quad$ Valid

\begin{tabular}{llll}
\hline $\mathrm{X}_{3-}$ Mechanism Reporting and & There is clear information disclosure. & 0.481 & Valid \\
$\begin{array}{l}\text { Mechanism distribution of } \\
\text { funds }\end{array}$ & Presentation of financial statements on time. & 0.623 & Valid \\
& Audits are conducted. & 0.539 & Valid
\end{tabular}

Source: Data processed (2019)

The following is the result of Cronbach's alpha testing.

Table 6. The result of Cronbach's Alpha Testing

\begin{tabular}{ccc}
\hline Construct & $\begin{array}{c}\text { Cronbach's } \\
\text { Alpha }\end{array}$ & Result \\
\hline Compliance of Zakat Accounting Practise Based on PSAK 109 & 0.836 & Reliable \\
The Role of the Internal Control System & 0.903 & Reliable \\
Financial Reporting Accountability & 0.725 & Reliable \\
\hline
\end{tabular}

Source: Data processed (2019)

Cronbach's alpha is a measure of reliability that has values ranging from zero to one (Ghozali, 2017; Joseph F. Hair Jr et al., 2019). The level of reliability of cronbach's alpha can be shown in the following table. 
Table 7. Reliability of Cronbach's Alpha

\begin{tabular}{cl}
\hline Cronbach's Alpha Score & Reliability level \\
\hline $0.0-0.20$ & Less reliable \\
$>0.20-0.40$ & Rather reliable \\
$>0.40-0.60$ & Pretty reliable \\
$>0.60-0.80$ & Reliable \\
$>0.80-1.00$ & Very reliable \\
\hline
\end{tabular}

Source: Ghozali, (2017)

As evident from the data above, the compliance of zakat accounting practice PSAK 109 and the role of the internal control system has a cronbach's alpha value above 0.80 , which is very reliable, and financial reporting accountability has an alpha cronbach's value $>0.60-0.80$, which is reliable. It can be concluded that the construct has good reliability. Thus, the research instrument can be used to examine the same data in relatively the same conditions, with the probability of reliable research results.

\section{Classic Assumption Test}

Based on the Kolmogorov-Smirnov test results, the value of $\mathrm{Z}$ for all variables is 0.098 , with a significant value (Sig2-Tailed) of $0.20>0.05$. It can be concluded that the data is normally distributed. Likewise, it can be seen in the histogram image of residual distribution data (error) showing an image in the form of a bell, and in a normal probability plot picture there is an error (in the form of a dot) around a straight line. The regression model meets the normality assumption, considered normally distributed.

Table 8 illustrates that the magnitude of the correlation between the independent variables has a fairly high correlation that is equal to 0.611 or around $61.1 \%$, but still below $95 \%$, so it can be said that there is no serious multicollinearity. The calculation results of the tolerance value indicate that there is no independent variable that has a tolerance value of $<0.10$, which means there is no correlation between independent variables whose value is more than $95 \%$. The calculation result of VIF value also shows that there is no independent variable that has a VIF value $>10$. From these conditions, it can be concluded that there is no multicollinearity between independent variables in the regression model.

Table 8. Multicollinearity Test Results

\begin{tabular}{lcccc}
\hline \multicolumn{1}{c}{ Model } & $\begin{array}{c}\text { Unstandardized } \\
\text { Coefficients }\end{array}$ & \multicolumn{3}{c}{ Collinearity Statistics } \\
\cline { 2 - 5 } & $\mathrm{B}$ & Std. Error & Tolerance & VIF \\
\hline (Constant) & 4.932 & 2.439 & & \\
$\begin{array}{l}\text { Compliance of Zakat Accounting Practise } \\
\text { Based on PSAK 109 }\end{array}$ & 0.011 & 0.058 & 0.611 & 1.638 \\
The Role of the Internal Control System & 0.131 & 0.050 & 0.611 & 1.638 \\
\hline
\end{tabular}

Source: Data Processed (2019)

In Figure 2 below, it can be seen that the variance of the residue does not have a certain pattern or is scattered randomly, so the regression does not contain elements of heteroscedasticity. 


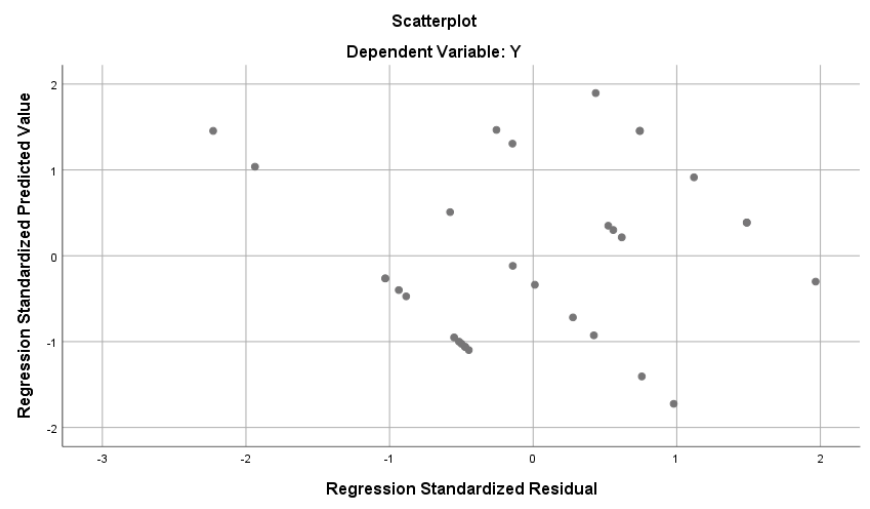

Figure 2. Heteroscedasticity Test Results

Likewise, utilizing a glejser test, the significance value of the compliance of zakat accounting practice based on PSAK 109 is 0.611 or more than 0.05 , while the internal control system role variable is 0.847 or more than 0.05 . It can be concluded that the regression model does not contain any indication of heteroscedasticity.

Goodness of Fit

From the data shown in Table 9, the amount of adjusted $\mathrm{R}^{2}$ is 0.208 , meaning $20.8 \%$ of variables in financial reporting accountability can be explained by variations of independent variables in both compliance of zakat accounting practice PSAK 109 and the role of the internal control system. The remaining $79.2 \%$ is explained by other causes outside the model, such as transparency and effectiveness in the management of zakat.

Table 9. Determination Coefficient Test Results

\begin{tabular}{ccc}
\hline Model & Adjusted R Square & Std. Error of the Estimate \\
\hline 1 & .208 & 1.211 \\
\hline
\end{tabular}

Source: Data Processed (2019)

Based on the F test table below, it can be seen that the significance of the test is 0.004 . This means the research model of compliance of zakat accounting practise based on PSAK 109, the role of the internal control system, and the financial reporting accountability that is being tested has been fit.

Table 10. F Test Results with ANOVA

\begin{tabular}{lllrl}
\hline Model & Sum of Squares & df & F & Sig. \\
\hline Regression & 18.351 & 2 & 9.175 & $.004^{\mathrm{b}}$ \\
Residual & 55.747 & 38 & & \\
Total & 74.098 & 40 & & \\
\hline
\end{tabular}

Source: Data Processed (2019)

\section{Hypothesis Testing}

The following is a table of test results for $t$ statistical significance. 
Table 11. t-Test Results

\begin{tabular}{|c|c|c|c|c|}
\hline \multirow{2}{*}{ Model } & \multicolumn{2}{|c|}{ Unstandardized Coefficients } & \multirow[t]{2}{*}{$t$} & \multirow[t]{2}{*}{ Sig. } \\
\hline & $\mathrm{B}$ & Std Error & & \\
\hline (Constant) & 4.932 & 2.439 & 2.022 & 0.050 \\
\hline $\begin{array}{l}\text { Compliance of Zakat Accounting Practise } \\
\text { Based on PSAK } 109\end{array}$ & 0.011 & 0.058 & 0.194 & 0.847 \\
\hline The Role of the Internal Control System & 0.131 & 0.050 & 2.638 & 0.012 \\
\hline
\end{tabular}

Source: Data Processed (2019)

From Table 11 above, it can be seen that compliance of zakat accounting practice based on PSAK 109 has a significant value of 0.847 , meaning that there is no significant effect of the compliance of zakat accounting practise based on PSAK 109 on financial reporting accountability at amil zakat institutions and amil zakat agencies in Jakarta and Banten provinces. On the other hand, the role of the internal control system has a significant value of 0.012 , meaning that there is a significant effect of the role of the internal control system variable on financial reporting accountability at the amil zakat agencies and amil zakat institutions in Jakarta and Banten provinces.

\section{Multiple Regression Test Results}

The constant of 4.932 shows that if the independent variables compliance of zakat accounting practice based on PSAK 109 and the role of the internal control system are assumed not to be carried out (equal to 0), then the value of financial reporting accountability is very small at $4.932 \%$. This shows the importance of compliance of zakat accounting practice based on PSAK 109 and the role of the internal control system towards the creation of financial reporting accountability.

The regression coefficient of the compliance of zakat accounting practice based on PSAK 109 is 0.011 . The coefficient is positive, so it can be concluded that there is a unidirectional relationship between compliance of zakat accounting practice based on PSAK 109 with financial reporting accountability. But in this study, the test results show that there is no significant effect of compliance of zakat accounting practice based on PSAK 109 on financial reporting accountability.

The regression coefficient of the role of the internal control system is 0.131 . The coefficient is positive, so it can be concluded that there is a unidirectional relationship between the roles of the internal control system with financial reporting accountability. In this case, if the role of the internal control system increases, financial reporting accountability will increase as well.

\section{Discussion}

4.1 The Influence of Compliance of Zakat Accounting Practise Based on PSAK 109 on Financial Reporting Accountability

Establishing if compliance of zakat accounting PSAK 109 practice does not have a significant effect on financial reporting accountability could be determined by whether the respondent is an amil zakat institution that is licensed or not licensed. LAZ, who are not licensed, do not feel they have an obligation to follow the zakat accounting PSAK 109 in the practice of accounting in their institutions, and compliance of zakat accounting PSAK 109 practice did not have a significant impact in increasing zakat funds at amil zakat institutions, according to respondents. PSAK 109, concerning zakat and infaq/shodaqoh accounting is a guideline for its management institution. With the adoption of this PSAK, it is expected that the uniformity of reporting and the simplicity of records can be realized so that the public can read the amil zakat accounting reports and oversee their management. In addition, the application of PSAK 109 aims to ensure that LAZ has used sharia principles and is used to measure LAZ's level of compliance with its application. However, based on the results of this study, amil zakat institutions have not fully followed the accounting practices of zakat accordance PSAK 109. From the results of this study there are still many amil zakat institutions that have not implemented PSAK 109 for financial reporting. In addition, many of the financial statements of amil zakat institutions have not been audited by public accounting firms. This result is consistent with research conducted Alim (2015; Doktoralina \& Bahari (2019; P \& Umah (2011; Restuningtyas, Marina, \& Nuraini (2017; Ritonga (2017; Trisnawati \& Megawati (2015) that compliance of zakat accounting PSAK 109 practice has no significant effect on financial reporting accountability. 


\subsection{The Influence of the Role of Internal Control Systems on the Financial Reporting Accountability}

The role of the internal control system has a positive significant effect on financial reporting accountability. The results of the study prove that the environment of control, the value of integrity and ethics, risk assessment, activities of control, information, communication, and monitoring were considered important by the respondents, and under such internal control reporting accountability is favourable. The amil zakat institutes have understood the importance of a good internal control system and implemented it in their management. This finding supports previous research conducted by Hamidi \& Suwardi (2013); Nikmatuniayah (2014); Nikmatuniayah \& Marliyati (2015); Wijaya, Adiputra, \& Darmawan, (2014) where influences testing of the role of internal controls on public accountability simultaneously showed excellent results in financial reporting accountability.

\section{Conclusions and Recommendations}

Based on the data that has been collected and the tests that have been carried out, it can be concluded that compliance of zakat accounting PSAK 109 practice has no significant effect on financial reporting accountability, possibly because there are still Amil Zakat institutions that have not fully implemented PSAK 109. The role of an internal control system has a positive significant effect on financial reporting accountability, proving that an amil zakat institution has understood the importance of a good internal control system and implemented it in the management of its institutions. LAZ wants to gain trust from the public, and it will with the accountability of financial reporting.

Amil zakat institutions must seek to increase understanding of the importance of the use of zakat accounting and the application of PSAK 109 to encourage good and responsible financial statements. accountability reporting can increase public confidence in amil zakat institutions. Based on research limitations, further research should focus on accountants' ethics for the application of internal control systems, such as ethics in recording Islamic transactions, by using this as a trigger for them to improve Islamic financial accountability. In particular, by increasing the number of samples, a methodological evaluation approach is used that involves sharia parameters and connects the variables of accountants' behavior, especially those related to zakat. For the public, recent research provides information that can provide insight and knowledge about decision making related to sharia transactions, especially zakat. For the government, the results of the current study indicate that the application of zakat accounting can not only maintain economic stability, but also benefit zakat management activities in society.

\section{Acknowledgement}

This research is the result of a research grant funded by the Indonesian Directorate General of Research, Technology and Higher Education. We would like to thank the Directorate General of Research, Technology and Higher Education for funding this research, as well as to Mercu Buana University for facilitating everything related to this research.

\section{References}

Aisyah, S. (2013). Analisis sistem pengendalian intern terhadap dana zakat pada Badan Amil Zakat (BAZ) di Kota Pare-Pare. Economix, 1(2), 114-125.

Alim, M. N. (2015). Utilization and accounting of Zakat for productive purposes in Indonesia: A review. 2nd Global Conference on Business and Social Science-2015, GCBSS-2015, 17-18 September 2015, Bali, Indonesia, 211, 232-236. https://doi.org/10.1016/j.sbspro.2015.11.028

Bastian, I. (2013). Akuntansi Sektor Publik Suatu Pengantar Edisi Ketiga. In Jakarta: Erlangga (Ketiga). STIM YKPN.

Committe of Sponsoring Organization of the Treadway Commission. (2013). COSO Internal Control - Integrated Framework. Committee of Sponsoring Organizations of the Treadway Commission.

Doktoralina, C. M., \& Bahari, Z. (2018). Zakat Accounting Information System in Private Higher Education. European Research Studies Journal, 21(3), 1-14.

Doktoralina, C. M., \& Bahari, Z. (2019). Integrity and Hisbah in The Zakat Management Mechanism on Zakat Institutions. Journal of Islamic, Social, Economics and Development (JISED), 4(26), 24-33.

Doktoralina, C. M., Bahari, Z., \& Abdullah, S. R. (2018). Mobilisation of Income Zakat Payment in Indonesia. IKONOMIKA: Jurnal Ekonomi Dan Bisnis Islam, 3(2), 179-194. https://doi.org/10.24042/febi.v3i2.3659

Doktoralina, C. M., Bahari, Z., Hassan, S. A., Ismail, N. A., \& Mardiyah, S. A. L. (2020). Hashtags as a way to expedite the zakat supply chain. Uncertain Supply Chain Management, 8(1), 197-206. 
https://doi.org/10.5267/j.uscm.2014.5.002

Doktoralina, C. M., Bahari, Z., Herliansyah, Y., Ismail, N. A., \& Putri, G. P. (2018). Role of Accounting Zakat as a Support Function in Supply Chain Management: A Resurrection of the Islamic Economy. International Journal of Supply Chain Management, 7(5), 336-342.

Doktoralina, C. M., Ilias, N. A., Bahari, Z., \& Suryadhi, J. (2019). Investment of Zakat Fund in Malaysia. The Journal of Social Sciences Research, 5(4), 999-1004. https://doi.org/10.32861/jssr.54.999.1004

Dulkiah, M. (2017). Peranan Lembaga Amil Zakat (Laz) Dalam Pemberdayaan Masyarakat Miskin Melalui Pengembangan Usaha Mikro Di Wilayah Jawa Barat. Jurnal Ilmu Sosial Dan Ilmu Politik UIN Sunan Gunung Djati Bandung, 1(1), 30-49. https://doi.org/10.15575/jp.v7i1.1735

Effendi, M. A. (2016). The power of good corporate governance: teori dan implementasi. In Jakarta: Salemba Empat (Kedua). Salemba Empat.

Ghozali, I. (2017). Aplikasi Analisis Multivariate dengan IBM SPSS 25 (Edisi 9). Diponegoro University Publishing Agency.

Hamidi, N., \& Suwardi, E. (2013). Analisis akuntabilitas publik organisasi pengelola zakat berdasarkan aspek pengendalian intern dan budaya organisasi (Survei pada organisasi pengelola zakat di Indonesia). Ekbisi, 8(1), 13-34.

Hermawan, S., \& Astriana, G. (2010). Akuntansi Zakat, Dan Upaya Peningkatan Transparansi Dan Akuntabilitas Lembaga Amil Zakat. Jurnal Ekonomi, 1(2), 34-42.

Joseph, F. H. Jr, Black, W. C., Barry, J. B., \& Anderson, R. E. (2019). Multivariate Data Analysis (8th ed.). Cengage Learning EMEA.

Lubis, H. Z., \& Saragih, I. S. N. (2018). Implementasi PSAK No. 109 Pada Badan Amil Zakat Sumatera Utara. Kumpulan Jurnal Dosen Universitas Muhammadiyah Sumatera Utara.

Mahmudi, M. (2013). Manajemen Kinerja Sektor Publik. In Akademi Manajemen Perusahaan YKPN, Yogyakarta.

Majelis Ulama Indonesia. (2011a). Fatwa Majelis Ulama Indonesia Nomor 13 tentang Hukum Zakat Atas Harta Haram (p. 3). Majelis Ulama Indonesia.

Majelis Ulama Indonesia. (2011b). Fatwa Majelis Ulama Indonesia Nomor 15 Tahun 2011 Tentang Penarikan, Pemeliharaan, Dan Penyaluran Harta Zakat (p. 5). Majelis Ulama Indonesia.

Majelis Ulama Indonesia. (2011c). Fatwa Majelis Ulama Indonesia Nomor 8 tentang Amil Zakat (p. 5). Komisi Fatwa Majelis Ulama Indonesia.

Mardiasmo. (2018). Akuntansi Sektor Publik (1st ed.). Andi.

Mursyidi. (2013). Akuntansi pemerintahan di Indonesia (Cetakan Ke). Refika Aditama.

Nikmatuniayah, N. (2014). Komparasi Sistem Pengendalian Internal Pengelolaan Lembaga AMil Zakat. Jurnal Akuntansi Multiparadigma, 5(3), 498-510. https://doi.org/10.18202/jamal.2014.12.5037

Nikmatuniayah, N., \& Marliyati, M. (2015). Akuntabilitas Laporan Keuangan Lembaga Amil Zakat di Kota Semarang. MIMBAR: Jurnal Sosial Dan Pembangunan, 31(2), 485-494. https://doi.org/10.29313/mimbar.v31i2.1562

P, A. K., \& Umah, U. K. (2011). Penerapan Akuntansi Zakat Pada Lembaga Amil Zakat (Studi pada LAZ DPU DT Cabang Semarang). Value Added| Majalah Ekonomi Dan Bisnis, 7(2), 68-97.

Restuningtyas, R. S., Marina, A., \& Nuraini, F. (2017). Accounting of Zakat, Infak and Alms in Transparency and Accountability in LAZ DOmpet Amanah Umat Sidoarjo. BALANCE: Economic, Business, Management and Accounting Journal, 14(01), 29-43.

Ritonga, P. (2017). Analisis Akuntansi Zakat Berdasarkan PSAK No. 109 Pada Badan Amil Zakat Nasional (BAZNAS) Sumatera Utara. KITABAH: Jurnal Akuntansi Dan Keuangan Syariah, 1(1), 1-19.

Sekaran, U., \& Bougie, R. (2016). Research Methods For Business: A Skill Building Approach (Abridged). John Wiley \& Sons Inc.

Septiarini, D. F. (2011). Pengaruh transparansi dan akuntabilitas terhadap pengumpulanhttps://doi.org/10.26740/jaj.v2n2.p172-199 dana zakat, infaq dan shodaqoh pada LAZ di Surabaya. AKRUAL: Jurnal Akuntansi, 2(2), 172-199. 
Setiyawati, H. (2013). The effect of internal accountants' competence, managers' commitment to organizations and the implementation of the internal control system on the quality of financial reporting. International Journal of Business and Management Invention, 2(11), 19-27.

Setiyawati, H., \& Doktoralina, C. M. (2019). The importance of quality accounting information management in regional governments in Indonesia. Management Science Letters, 9(12), 2083-2092. https://doi.org/10.5267/j.msl.2019.6.025

Susanto, A. (2017). Sistem informasi akuntansi: pemahaman konsep secara terpadu. Lingga Jaya.

Taha, R., Adam, F., Ali, N. N. M., \& Ariff, A. M. (2017). Religiosity and transparency in the management of zakat institutions. Journal of Legal, Ethical and Regulatory Issues, 20(1), 1-9.

Trisnawati, D., \& Megawati, F. (2015). Penerapan PSAK 109 Tentang Akuntansi Zakat dan Infak/Sedekah pada BAZ Kota Pekanbaru. Kutubkhanah, 17(1), 40-59.

Tuanakotta, T. M. (2015). Audit kontemporer. In Jakarta: Salemba Empat. Salemba Empat.

Penyelenggaraan Negara Yang Bersih dan Bebas dari Korupsi, Kolusi, dan Nepotisme, 18. (1999). Retrieved from https://www.kpk.go.id/gratifikasi/BP/uu_28_1999.pdf

Vance, A., Lowry, P. B., \& Eggett, D. (2015). Increasing Accountability Through User-Interface Design Artifacts: A New Approach To Addressing The Problem Of Access-Policy Violations. MIS Quarterly, 39(2), 1.18. https://doi.org/10.25300/MISQ/2015/39.2.04

Widiana, W. (2018). Analisa Perkembangan Peraturan Peraturan dan Penerapan Akuntansi Syariah di Indonesia. Law and Justice, 2(2), 168-176. https://doi.org/10.23917/laj.v2i2.3837

Wijaya, J., Adiputra, I. M. P., \& Darmawan, N. A. S. (2014). Pengaruh Implementasi Pengendalian Intern, Budaya Organisasi dan Total Quality Management Terhadap Penerapan Good Governance pada Dinas Pendapatan Daerah Kabupaten Buleleng. JIMAT (Jurnal Ilmiah Mahasiswa Akuntansi) Undiksha, 2(1). https://doi.org/10.23887/jimat.v2i1.4395

\section{Copyrights}

Copyright for this article is retained by the author(s), with first publication rights granted to the journal.

This is an open-access article distributed under the terms and conditions of the Creative Commons Attribution license (http://creativecommons.org/licenses/by/4.0/). 